\title{
THE PROCESS OF CLOSING DOWN RURAL LANDFILLS CASE STUDY: NEAMT COUNTY
}

\section{Liviu Apostol ${ }^{1}$, Florin-Constantin Mihai ${ }^{2}$}

Key words: rural landfill, EU acquis, territorial review, sanitation services, rehabilitation.

\begin{abstract}
Landfilling is the main method for municipal waste disposal in Romania. Access to sanitation services are limited on rural territory and that leads to uncontrolled waste disposal with negative implications on the geosystem. Implementation of EU acquis on waste disposal from rural areas requires local authorities to close the landfills by July 16, 2009. Following this deadline, municipalities are obliged to provide waste collection and transportation to the existing urban landfills. Under these conditions,this article is proposing a territorial review of closing and rehabilitation of rural landfills from Neamt county. Also, this paper analyzed the existing environmental dysfunctions supported by field observations.
\end{abstract}

\section{Introduction}

Waste management in rural areas is rudimentary in developing countries and the access to sanitation services is limited. A large part of the waste generated is mainly biodegradable and it's beeing used as biofuel in their households, less waste is recovered and uncontrolled landfills are a real risk to the environmental and human health. In developed countries, $90-100 \%$ of the population has access to sanitation services(OECD,2008).Also,these countries implemented integrated waste management systems that focus on : recycling, recovery, composting, selective waste collection, incineration with energy recovery .The final disposal is done in sanitary landfills and waste management services belong to the private sector.

Cooperation between local authorities is developed, leading to lower cost of sanitation services in rural territory.(Germà,Mur, 2009).

Landfill Directive 1999/31/EC is focused on reducing the amount of waste landfilled and less on prevention of waste. Landfilling is the the main choice of waste disposal for the new Member States.Uncontrolled disposal still takes place in

\footnotetext{
${ }^{1}$ Prof. PhD., Alexandru Ioan Cuza University, Iasi, apostolliv@yahoo.com

${ }^{2} \mathrm{PhD}$. Student, Alexandru Ioan Cuza" University, Iasi ,mihai.florin86@yahoo.com
} 
rural areas from Cyprus (Athanassiou, Zabaniotou, 2007),or Romania. The new Directive 2008/98 focuses on waste prevention.

\section{The legislative framework in Romania}

The Landfill Directive 1999/31/EC was transposed into national law (H.G. nr 345 /2005) Ministry of Environment and Sustainable Development has developed a program for closing urban landfills that does not complies with the EU acquis, for the period 2005-2017.

In addition to urban landfills , approximately 2686 rural landfills were identified in 2004 with an area of less than 1 ha $($ ANPM,2007) In the same year in Poland, there were 806 rural landfills with a total area of 2421 ha. (Kulczycka, Zygmunt, 2008).The share of population served by sanitation services in rural areas was only $22 \%$ in 2008 .This explains that for the same year were identified over 5,000 rural landfills, with an area of less than 1 ha. (ANPM,2009) The closure and rehabilitation of rural landfills had as deadline 07/16/2009. Inventory of these sites , their closure and rehabilitation monitoring was done under a control procedure by members of the National Environmental Guard and Environmental Protection Agency from each county. Ministry of Environment and Sustainable Development by issuing a normative act (O.M. nr 1274/2005), establishes the measures for closing small and non hazardous landfills from rural teritory. The criteria for these sites are : smaller volume than 20,000 cubic meters, less than 1 ha area $(10,000$ square meters), there is only household waste or similar waste and inert waste (glass, stones, ash, pottery, etc.) without hazardous waste

Also establishes procedures for closure and rehabilitation of these sites:

- Waste electrical and electronic equipment, batteries, used tires, ferrous waste, furniture or construction waste and demolition waste will be extracted from the landfill and will be separately disposed

- Waste should be compacted with a bulldozer

- landfill should be uniform and soil covered

- uniformly seeded grass, (mowing) for 2 years

- these sites should be identified and properly marked for the cadastral records

These rural landfills by Minister Order nr 636/2008, were excepted from the application of H.G nr 349/2005 on waste disposal ,also from obtaining of the environmental agreement in order to establish obligations regarding the restoration of environmental quality of these sites.

\section{The closure and rehabilitation of rural landfills in Neamt County}

County Environmental Protection Agency identified 126 rural landfills, located in 61 communes and covering an area of approximately 82.33 hectares, in 
December 2008. This article is based on processing data from the report of rural landfills (27.09 2009) prepared by County Commissariat of the National Environmental Guard. According to data processing,it results a number of 122 rural landfills with an area of 23,626 ha and an estimated volume of $118,820 \mathrm{~m}^{3}$, located in 64 communes.

Rural landfills have a total area of 23,626 ha, over 50\% smaller area of 0.05 ha and only four sites have an area of over 1.1 ha (fig.1)

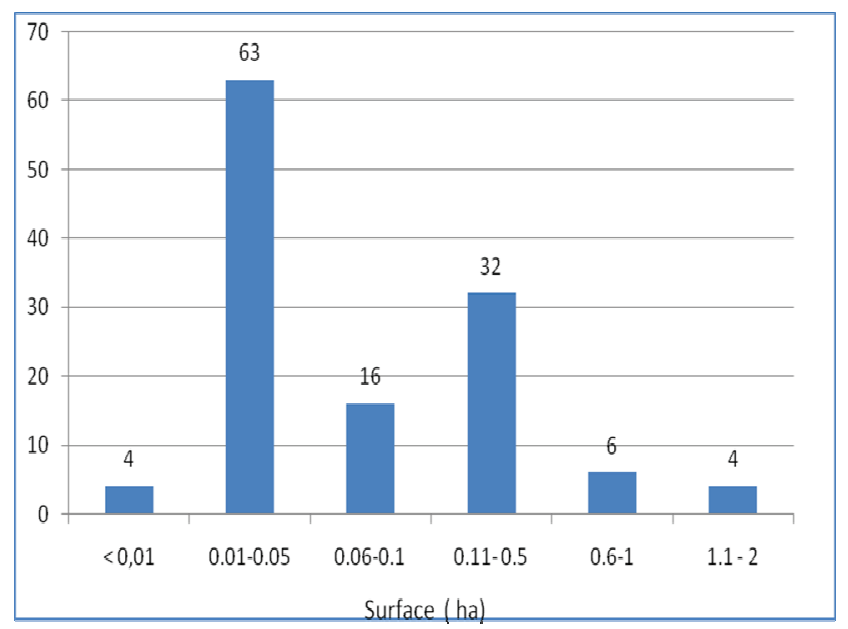

Fig. 1 - The number and estimated areas (ha) of rural landfills Aug. 2009 Data source : GNM Neamț (processing database)

Most of them are located in the Subcarpathian and plateau area of the county unlike the mountain area where rivers are damaged by uncontrolled disposal of waste.

According to the occupied areas, most rural landfills have small volumes ranging between $10-50 \mathrm{~m}^{3}$, and only 22 landfills have more than $600 \mathrm{~m}^{3}$.

High values for the mountain region, is explained by sawdust landfill due to forest exploitation (ex. Grințies commune) Data on surface and volume of waste is estimated that requires caution in their interpretation.

In 2007, only $9.08 \%$ of the rural population in Neamt County was served by sanitation services (APM Neamt, 2009) Under these conditions, most of the waste generated and uncollected, is partially recovered in their own households, and remaining waste is disposed as uncontrolled landfills that damage rivers especially in the mountain area or agricultural lands, local roads, built-up areas,in 
the rest of the territory .Municipalities are obliged to provide waste collection services and to ensure their transportation to urban landfills (Roman and Târgu Neamț).

The main measures for the rehabilitation of rural landfills are:

- Moving them to urban landfills (Roman or Târgu Neamț)

- compacting and soil cover

- grass seeding.

Some communities from the mountain area reported they didn't have rural landfills. Field observations from September 2009 showed that the rivers from their teritory have been damaged by uncontrolled household waste disposal(fig.2)

Uncontrolled disposal of waste also takes place in the eastern municipalities of the county (Răuceşti, Poienari) The local authorities which didn't report such sites, are contradicted by the field observations (fig.3).

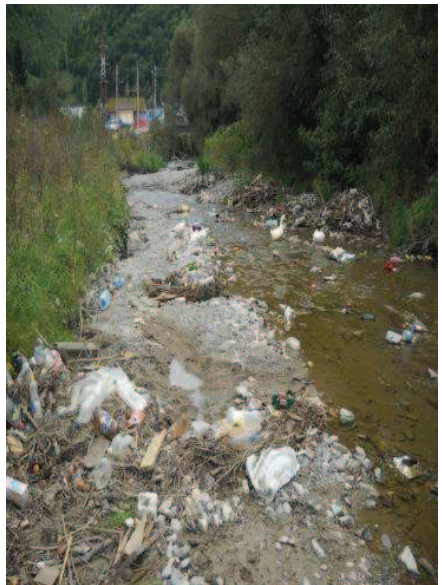

Fig. 2 - Jidan river damaged by uncontrolled waste disposal, Bicaz Ardelean commune,september 2009

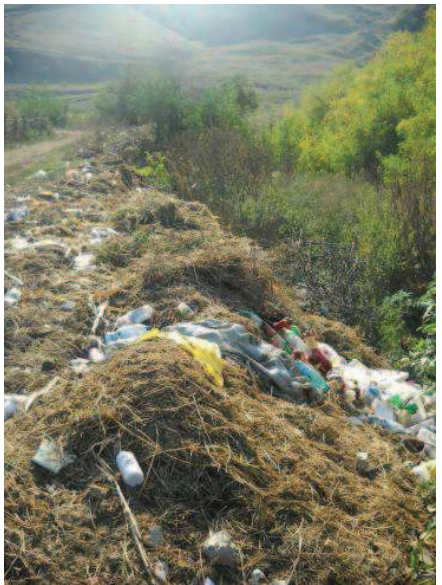

Fig.3 - Uncontrolled landfill, Săcăleni village (Poienari commune) September 2009

Although the deadline for closing the rural landfills was July 16, 2009, at the end of August, there were still 11 open sites : 4 of them in Icuseşti, 3 in Dumbrava Roşie and one for each in Pângărați,Piatra Şoimului,Borleşti and Tarcău . About 25 landfills have stopped activity but have not started their rehabilitation .

Most sites have been compacted and covered with soil and only 11 landfills were grassed (fig 4). This may be due to additional costs of the local authorities budget, because a grassy area should be cared almost two years, only thus ensuring a faster rehabilitation of the landfill. 


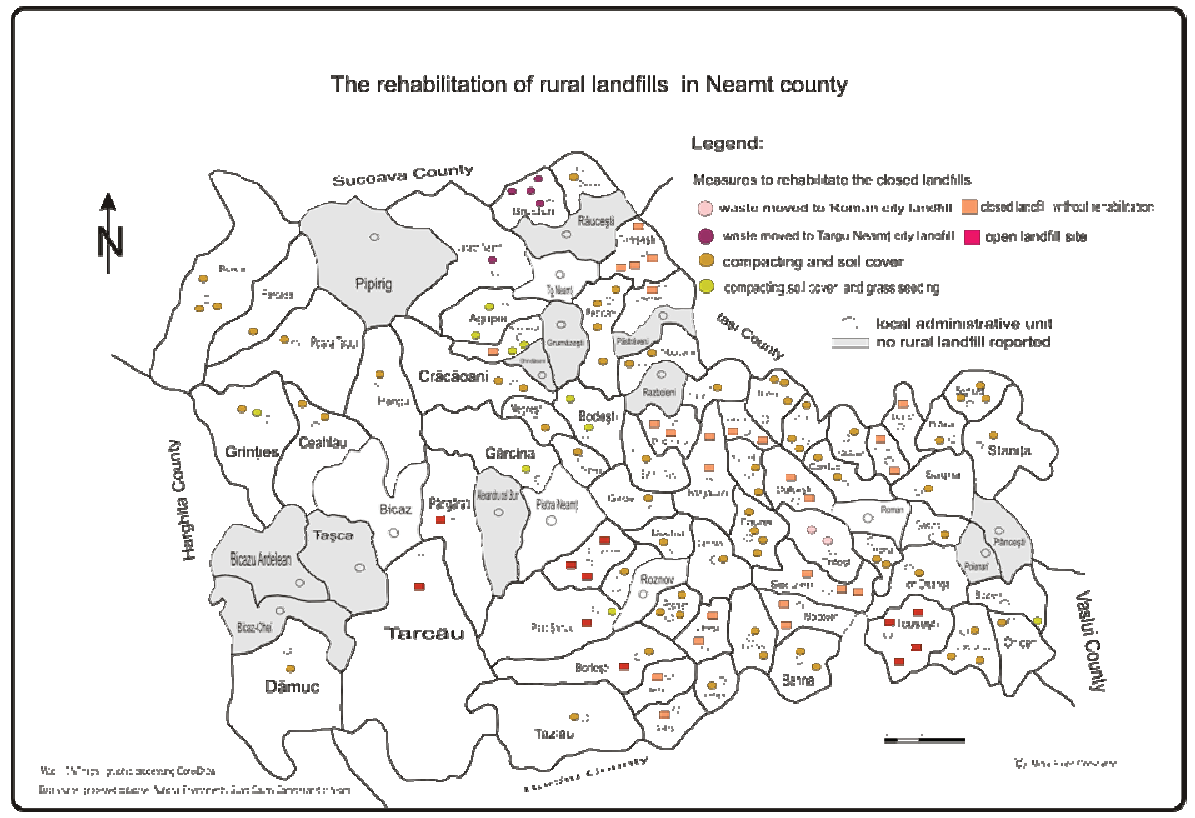

Fig.4 - The closure and rehabilitation of rural landfills ( the end of August 2009)

Soil cover and compacting does not eliminate percolation of the rainwater, which penetrates these landfills. Because of that, collection of hazardous waste as waste electrical and electronic equipment (WEEE), tires, batteries, accumulators, etc., before implementation of rehabilitation measures played an important role to reduce sources of pollution of soil and groundwater.Moreover, these storage contain both household waste (including potentially toxic waste) and sawdust, wood waste, agricultural waste, inert waste.

Local authorities have the responsibility to collect this types of waste There was no evidence of potentially toxic waste extracted from landfill areas. The biodegradable waste has a high percentage in Neamt county with a value over $68.1 \%$ in 2008 (APM , 2009), for rural areas this value is probably higher.Thus, there is risk of pollution with organic matter of rivers and groundwater in the proximity of these sites.

Unfortunately, there is no specific studies on household waste composition analysis in rural areas or to determine the environmental impact of such a site.Soil cover and compaction of landfills limits atmospheric emissions and the risk of accidental or deliberate fire. Occupied lands are issued in a short period of time by moving waste to urban landfills (Târgu Neamț and Roman). Thus are limited local 
sources of pollution. In terms of environmental protection is a good measure but less economically viable due to high costs of transport of these wastes .It is sustainable for small landfills located in proximity to urban settlements.

The largest areas of sites have been compacted and covered with soil (about 18 ha with an estimated volume of $68,725 \mathrm{~m}^{3}$ ), but, only 0.81 ha were grassed, with an estimated volume of $3170 \mathrm{~m}^{3}$.(fig. 5)

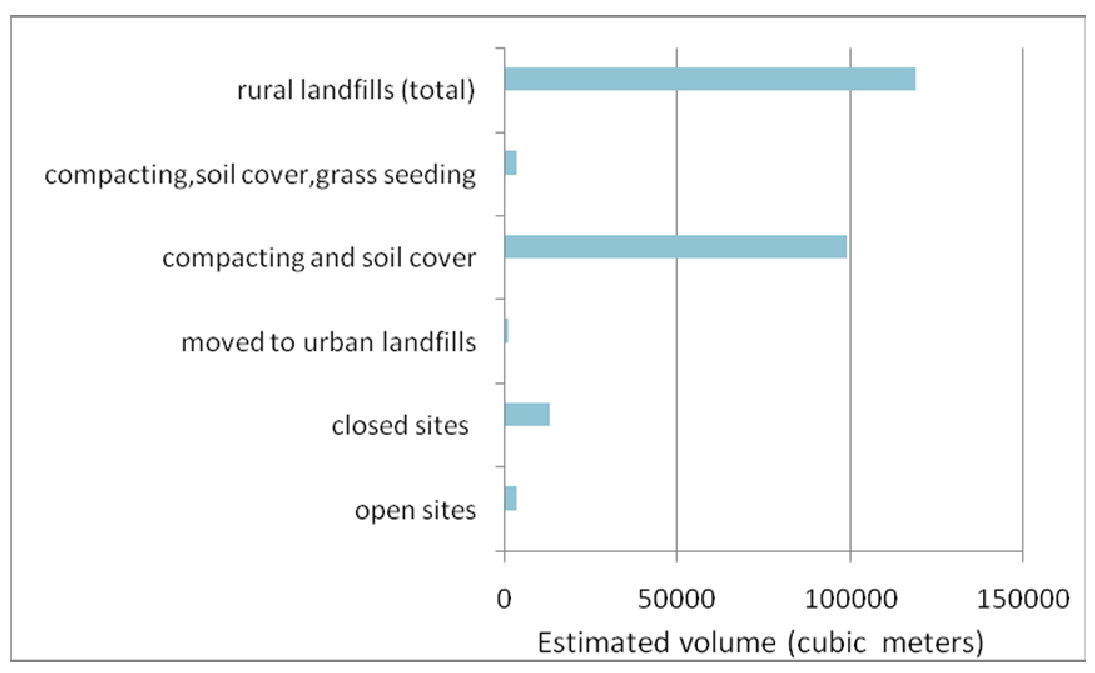

Fig.5 - Estimated volumes of rehabilitated rural landfills until August 2009 Data source : GNM Neamț (processing database)

Rural sites moved to urban landfills had an estimated total area of 0.315 ha and a volume of $13745 \mathrm{~m}^{3}$.

Uncontrolled landfills (those suspended and open dumps until the end of August 2009) covered an area of about 4.515 ha with an estimated volume about $13745 \mathrm{~m}^{3}$ Some suspended or abandoned landfills were grassed or ruderal vegetation has developed.Usually these sites occupy very small areas, low volumes, a large proportion of biodegradable waste.Field observations from September 2009 and April 2010 show that, the local population still dispose the waste on these closed sites or on their proximity (fig.8,9)

Also, the commissioners of Environmental National Guard made field inspections for monitoring the closure and rehabilitation of these landfills .They fined local authorities that didn't respect the legal procedures. 


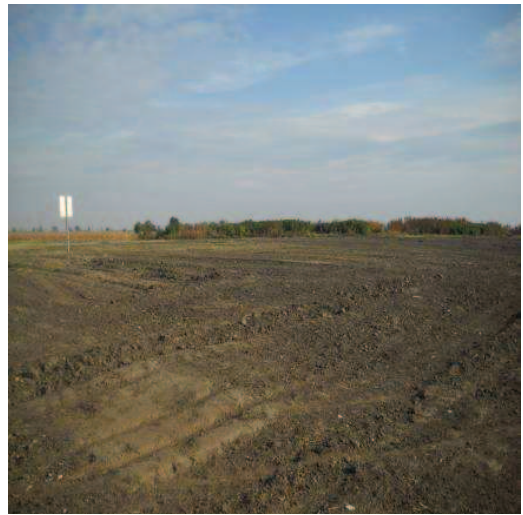

Fig.6 - Closed rural landfill - compacted and soil covered,positive model, Gherăieşti commune,september 2009

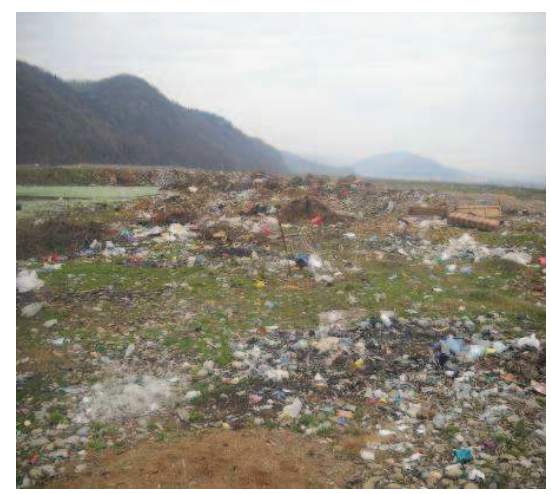

Fig.8 - "Closed" rural landfill,

Dumbrava Roşie commune , april 2010

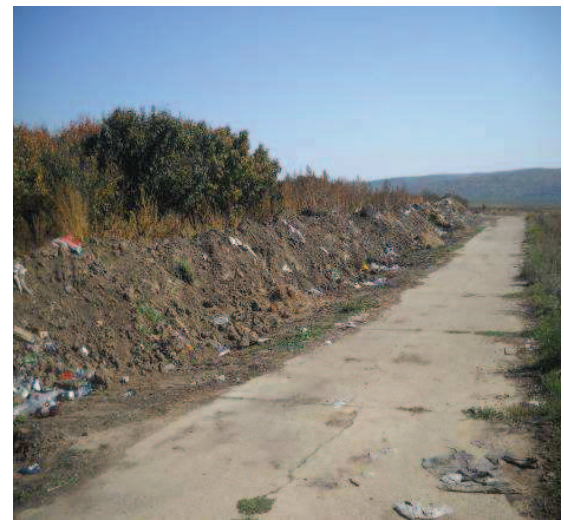

Fig.7 - Closed rural landfill - soil covered, uncompacted, negative model,Bozieni commune, September 2009

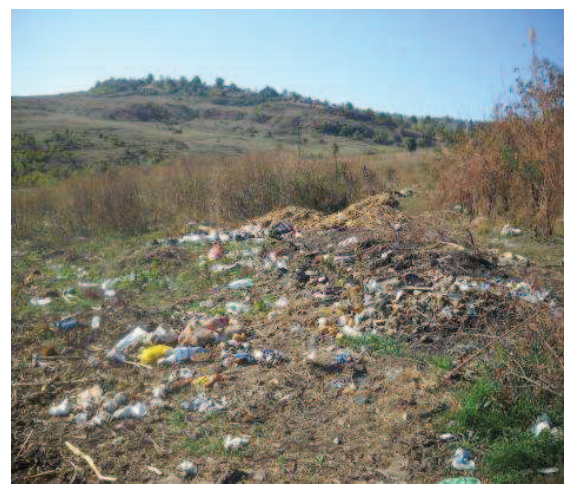

Fig.9 - Uncontrolled waste disposal Valea Ursului commune, september 2009

\section{Conclusions}

The landfill areas and volumes were generally low, except for villages with high population densities in the eastern county (ex. Săbăoani,Gherăieşti).Lowest economic level of the region compared to southern or western Romania cause a lower degree per capita waste generation. Neamț county is mostly rural population, this category represents about $62.1 \%$ of total county population (APM, 2009), only $10 \%$ of them (the average 2005-2008) was served by sanitation services

This leads to uncontrolled disposal of their household waste in the river beds, the roadsides, agricultural areas, built-up areas, etc. becoming sources of soil and groundwater pollution. 
Moreover, these landfills are usually located near human settlements, being a health threat to humans and livestock. There are communities that didn't respect the deadline for closing landfills. Environmental investment plans of local authorities from 2008 and 2009 were provided for the closure of uncontrolled landfills. The most sites have been compacted and covered up with soil. Some of these are not properly marked or they were superficial closed .

Because the lack of waste management infrastructure ,uncontrolled disposal of waste still takes place today in rural teritory. Most rural landfills are located in the eastern part of the county, unlike the western mountain area, where rivers are damaged by uncontrolled disposal of household waste and sawdust.

However, since 2009, several communities have signed contracts for waste collection and their transportation to urban landfills (Roman and Târgu Neamț) until the project of integrated municipal waste management system will be implemented in Neamț County.

\section{Acknowledgements}

This work was supported by the the European Social Fund in Romania, under the responsibility of the Managing Authority for the Sectoral Operational Programme for Human Resources Development 2007-2013 [grant POSDRU/CPP 107/DMI 1.5/S/78342].

\section{References:}

Athanassiou, M., Zabaniotou, A. (2007), Techno-economic assessment of recycling practices of municipal solid wastes in Cyprus, Journal of Cleaner Production, 16 (2008) 1474-1483.

Bel, Germà, Mur, Melania (2009), Intermunicipal cooperation, privatization and waste management costs: Evidence from rural municipalities, Waste Management, 29, p. 2772-2778.

Kulczycka, Joanna, Zygmunt, K. (2008), Principles of municipal waste management in Poland and selected regions of Europe, Polish Journal of Chemical Technology, vol. 10, nr. 4, p 28-33.

*** (1999), Council Directive 1999/31/EC of 26 April 1999 on the landfill of waste.

*** (2008), DIRECTIVE 2008/98/EC OF THE EUROPEAN PARLIAMENT AND OF THE COUNCIL of 19 November 2008 on waste and repealing certain Directives.

*** (2005), HG nr.349 din 21 aprilie 2005 privind depozitarea deşeurilor (completata prin $H G$ nr. 210/2007). 